\title{
LA HISTORIA DE UNA GRAN AMISTAD
}

\section{David Gallagher}

Tras resumir las múltiples facetas del Quijote, el artículo se detiene en una de ellas, la amistad de don Quijote y Sancho Panza, dos personajes mucho más complejos que los estereotipos que existen de ellos y mucho más parecidos entre sí de lo que a veces se cree. Los dos comparten un proyecto de vida. Los elementos claves de la compleja amistad, basada en complicidades y en engaños, quedan establecidos al regresar Sancho a la Sierra Morena, tras su fallida embajada a Dulcinea. Los dos van urdiendo un pacto epistemológico en que, a diferencia de Anselmo en "El curioso impertinente", evitan que su proyecto de vida sea vulnerado por un exceso de verdad. Los dos amigos son leales el uno al otro, pero con diversos grados de intensidad, asomándose a veces incluso a la traición. La principal diferencia entre los dos es que el uno es el amo y el otro el criado, el uno el emprendedor e instigador, y el otro el empleado y seguidor. Pero los dos se necesitan y se sienten muy vulnerables cuando están separados. Los dos valoran la libertad recuperada cuando se despiden de los Duques. Los dos aceptan que la "comedia" que han jugado tiene un límite, por lo que es lógico que don Quijote muera renegando de ella, sin que por su lado Sancho proteste demasiado.

DAVID Gallagher nació en Valparaíso en 1944. Educado en Oxford, fue luego profesor de literatura latinoamericana del St. Antony's College de esa misma Universidad. Ha publicado Modern Latin American Literature (Oxford University Press, 1973), Improvisaciones (Centro de Estudios Públicos, 1992), Otras improvisaciones (El Mercurio-Aguilar, 2004) y numerosos ensayos. Fue Director del Morgan Grenfell International \& Co. Ltd. Actualmente es socio de ASSET-CHILE y combina sus actividades como ensayista y crítico con las de banca de inversiones. Colabora con el TLS (The Times Literary Supplement) y es columnista de El Mercurio de Santiago. Es miembro del Consejo Directivo del Centro de Estudios Públicos.

Estudios Públicos, 100 (primavera 2005). 


\section{Prólogo}
$\mathrm{iT}_{\mathrm{T}}$
antas novelas en una! La de caballería. La que satiriza a las novelas de caballería. La de las églogas y las novelas pastoriles. La que comprende numerosas novelas y cuentos interiores, cuyos personajes se conocen y se entrelazan, a pesar de encontrarse en diversos planos ontoló- gicos, a primera vista incompatibles. La que explora los misterios de la locu- ra, sobre todo aquella que, por ser intermitente, se confunde con la más plácida cordura. La que explora la movediza y delgada línea entre fantasía y realidad, o la brecha entre la voluntad y el deseo por un lado, y los no siempre porfiados hechos por otro. La novela que explora el arte de novelar, y que desde sus dimensiones meta-fícticas, va midiendo y sopesando los invasores alcances de la ficción. La novela que, con sus variadas capas de narración, expone el dudoso y cambiante status ontológico de cualquier narrador. La que revela el comienzo de la decadencia de una España hasta hace poco heroica. La novela sobre la belleza del arrojo que no se detiene ante el cálculo. La novela cuya primera parte ha sido leída por sus propios personajes, que aparecen además en una odiosa versión apócrifa, que tam- bién han leído. La novela que, por eso mismo, tiene, según Borges, entre sus "magias parciales", el hecho de que nos hace parecer, o ser, irreales, ya que si nosotros leemos sobre personajes que también son lectores de la obra en que están, será que también nosotros estamos en una obra en que nos leen ${ }^{1}$. La novela que nos transforma y enriquece la lectura de novelas anteriores de acuerdo a la tesis de un T.S. Eliot o un Borges, de que cada monumento literario altera a los que lo precedieron. La novela que por la misma razón altera nuestra lectura de toda novela posterior ${ }^{2}$. La novela de incontables capas de humor: del humor sutil entre líneas, al humor erudito de las parodias, a, finalmente, la comedia de golpes y porrazos, con sus incontables caídas del caballo, en que el chiste, a veces cruel, está en la brecha entre la descabellada fantasía o voluntad de don Quijote y Sancho, y la tierra a la que caen, la tierra que están obligados a pisar. Novela de extraordinarios espectáculos visuales, espectáculos épicos con ribetes su- rrealistas, cuyo origen a veces está en una modesta metáfora: por ejemplo que un ejército lejano se parezca a una vasta manada de ovejas. Novela entonces sobre la locura de creer que la relación que implica una metáfora

\footnotetext{
2 Ver T.S. Eliot, "Tradition and the Individual Talent", The Sacred Wood
}
${ }^{1}$ Jorge Luis Borges, "Magias parciales del Quijote" (1952), Obras Completas, Tomo II (Buenos Aires: Emecé, 1996), pp. 45-47. (London: Methuen, 1920), y Borges, Obras Completas, op. cit., "Pierre Menard, autor del Quijote", Tomo I, pp. 444-450, y "Kafka y sus precursores", Tomo II, pp. 88-90. 
es de dirección doble ${ }^{3}$. Novela de amor en todas sus fases, de la más idílicamente pastoril a las más ruda y terruña. Novela antes que todo de amistad; de una insólita y entrañable amistad entre dos hombres a primera vista dispares, dos hombres de carne y hueso que en la novela real nunca permiten que se les encasille en estereotipos, a pesar de que se convertirán en tales en la leyenda que se irá formando sobre el libro.

\section{Del reclutamiento de Sancho, a la separación en la Sierra Morena}

\subsection{Almas gemelas}

Los principales elementos de esta compleja amistad entre dos personas más parecidas de lo que la leyenda admite, dos personas que se han "conocido desde su nacimiento", se dan en el corto período que media entre la primera salida del Quijote y Sancho juntos, y el regreso de un mal acompañado Sancho a la Sierra Morena, donde don Quijote lo está esperando, tras una delicada embajada que le ha encomendado. A veces se cree, o que Sancho y Quijote son irremediablemente distintos, dos polos opuestos, o que la influencia mutua entre los dos amigos - lo que Salvador de Madariaga veía como la paulatina quijotación de Sancho y sanchificación del Quijote ${ }^{5}$ - se va dando sólo en forma paulatina y mucho después. Pero en este breve trecho uno ya ve un Sancho a veces tan iluso como don Quijote o cómo él mismo será cuando gobierne la ínsula, y a un don Quijote perfectamente capaz de pisar tierra tanto o más que Sancho. En realidad Sancho sale con don Quijote desde el comienzo impelido por la promesa de que "tal vez le podía suceder aventura que ganase, en quítame allá esas pajas, alguna ínsula, y le dejase a él por gobernador de ella" ${ }^{" 6}$. Es con esa promesa que, "sin despedirse de sus hijos y mujer", Sancho parte con don Quijote en la noche, "sin que persona los viese"7. Ese desde el primer día iluso y fantasioso Sancho Panza es el que la leyenda ha de ver como un adalid de la sensatez.

${ }^{3}$ Dice el ventero, en su discusión sobre novelas de caballería con el cura, que Felixmarte de Hircania desbarató un ejército de "un millón seiscientos mil soldados . . . como si fueran manadas de ovejas", p. 324. El lector sabe que don Quijote ha encarnado el revés de la metáfora, arremetiendo contra una manada de ovejas como si fuera un ejército.

${ }^{4}$ Miguel de Cervantes, Don Quijote de la Mancha, edición del IV Centenario (Alfaguara, 2005), p. 116.

${ }^{5}$ Salvador de Madariaga, Guía del lector del Quijote (Buenos Aires: Editorial Sudamericana, 1947).

${ }^{6}$ Cervantes, Don Quijote, op. cit., p. 72.

${ }^{7}$ Ibídem, p. 73. 
Uno podría objetar que la credulidad de Sancho en este comienzo se debe a su ignorancia de labrador, pero que después, cuando ve a don Quijote batirse contra los molinos de viento, la primera aventura que tendrán juntos, florecerá su realismo. Así ocurre por un momento, pero casi de inmediato después, puede más la fantasiosa codicia de Sancho que su supuesto apego a la realidad. Justo después del episodio de los molinos, don Quijote arremete contra los frailes de San Benito, por creer que son encantadores y que en el coche que acompañan, "llevan hurtada alguna princesa". La acción la emprende don Quijote ante el asombro y contra las advertencias de un Sancho tan "realista" como lo fue durante la aventura de los molinos. Pero pronto Sancho comenzará a quitarle los hábitos al fraile que don Quijote ha derrumbado, con el argumento de que hacerlo "le tocaba a él legítimamente, como despojos de la batalla que su señor don Quijote había ganado"9. Es allí donde Sancho, que ha ayudado a su amo a levantarse tras el doloroso porrazo que se ha dado contra los molinos, recibe él mismo su primera paliza. "Sin dejarle pelo en las barbas", los mozos que acompañaban a los frailes "le molieron a coces y lo dejaron tendido en el suelo, sin aliento ni sentido"10. Durante toda la novela, tanto el caballero andante como el generalmente fiel escudero recibirán incontables palizas que los harán pisar e incluso tragar tierra y verter sangre. Pero no será minada la envidiable capacidad que ambos tienen, como en un comic, de levantarse de nuevo y volver a sus aventuras.

\section{2. ¿Quién manda a quién?}

Cuando parten para la Sierra Morena, para escaparse de la Santa Hermandad que Sancho supone ha de salir a detenerlos por haber liberado a los galeotes, don Quijote y Sancho han tenido algunos triunfos pero han sufrido muchos golpes. Don Quijote ha vencido al vizcaíno, Sancho ha padecido el hambre, don Quijote ha alabado la edad de oro en que se vivía en paz y en que toda propiedad era compartida, y los dos han oído impresionantes historias como la de la pastora Marcela o la del despechado Ambrosio. Don Quijote ha sido burlado, y Sancho manteado, en una venta, y los dos han vomitado el uno sobre el otro, tras probar el bálsamo de Fierabrás. Don Quijote ha embestido contra un rebaño de ovejas, y los dos, en un arrebato de realismo, se han reído a carcajadas al descubrir que un por-

\footnotetext{
8 Ibídem, p. 79.

9 Ibídem, p. 80.

${ }^{10}$ Ibídem, p. 80
} 
tentoso ruido que los había desvelado toda la noche, no era producido por encantadores gigantes, sino por "seis mazos de batán"11.

La risa espontánea de ambos ha desembocado enseguida en un ataque de cólera de parte de don Quijote, que tal vez arrepentido de haber aceptado tan fácilmente que los batanes eran en realidad simplemente batanes, le ha advertido a Sancho que a un escudero no le corresponde reírse de su amo. "Es menester", le advierte don Quijote a Sancho, "hacer diferencia de amo a mozo, de señor a criado y de caballero a escudero" 12 . Es la primera vez que don Quijote ha recurrido en forma tan explícita a su ascendencia jerárquica sobre Sancho, para imponer su versión de los hechos. Es la primera vez que don Quijote hace con Sancho lo que ya ha hecho muchas veces con la gente con que ambos se han encontrado en el camino: demostrar que en fin de cuentas, la verdad la tiene el más poderoso y mejor armado.

Inmediatamente después, don Quijote ha de insistir que la bacía que lleva un barbero con que se encuentran, es nada menos que el codiciado y potente yelmo de Mambrino. Sancho, aleccionado por las consecuencias de su carcajada ante los mazos de batán, no se animará a contradecirlo cuando don Quijote arremete contra el barbero para recuperar el yelmo para la caballería andante. Entregado a la fantasía de su amo, aunque la encuentra descabellada, Sancho más bien decide aprovecharse materialmente de la situación: cambia los aparejos del asno que el barbero deja al huir, por los aparejos más pobres de su propio rucio.

De allí, tras un diálogo en que don Quijote y Sancho han intercambiado las más descabelladas fantasías sobre las glorias futuras que los esperan, don Quijote libera a los prisioneros encadenados que llevan a las galeras. Las personas favorecidas por el heroísmo de don Quijote no siempre lo agradecen: los ingratos apedrean a don Quijote y Sancho, y de allí los entrañables amigos parten a la Sierra Morena.

Parten después de una discusión en que esta vez don Quijote se pliega a las recomendaciones de Sancho. Don Quijote se deja convencer que es prudente huir a la Sierra mientras los busque la Santa Hermandad, a pesar de su temor al "que dirán". Don Quijote acepta ir a esconderse en la Sierra Morena siempre y cuando Sancho jure nunca contarlo:

[J]amás en vida ni en muerte has de decir a nadie que yo me retiré y aparté de este peligro de miedo sino por complacer a tus ruegos; que si otra cosa dijeres mentirás en ello, y desde ahora para entonces y desde entonces para ahora te desmien-

\footnotetext{
${ }^{11}$ Ibídem, p. 184.

12 Ibídem, p. 186.
} 
to y digo que mientes y mentirás todas las veces que lo pensares o lo dijeres ${ }^{13}$.

En la Sierra Morena tras este arrebato que demuestra que no sólo Sancho es pícaro y sensato (para no decir cobarde), y que no sólo don Quijote lleva la ascendencia en la toma de decisiones, se consolida de una vez la amistad del amo y el escudero. Se consolida un proyecto de vida, uno que es primordialmente de don Quijote y al que don Quijote ha llamado a Sancho, pero en el cual Sancho es cómplice y beneficiario.

\subsection{La ilusión confirmada}

Un hecho muy significativo al entrar a la Sierra Morena es el hallazgo de una maleta con cien ducados de oro. Don Quijote le permite a Sancho guardarlas para sí. Por primera vez Sancho ve convalidadas las promesas de don Quijote, de que la caballería andante conduce a la riqueza y al poder. Con el hallazgo, Sancho

[D]io por bien empleados los vuelos de la manta, el vomitar del brebaje, las bendiciones de las estacas, las puñadas del arriero, las faltas de las alforjas, el robo del gabán, y toda la hambre, sed y cansancio que había pasado en servicio de su buen señor, pareciéndole que estaba más que recién pagado con la merced recibida de la entrega del hallazgo ${ }^{14}$.

Enseguida los amigos se encontrarán con Cardenio, un hombre que se ha retirado a la montaña tras ser despechado por Luscinda: después descubrirán que Cardenio era el dueño de la maleta. Cardenio es, como don Quijote, un personaje lúcido y sensato, pero trastornado por una idea fija, que lo tiene a veces asido por "el accidente de la locura"15. Personaje de otra novela, Cardenio, ahora cuerdo, ahora loco, es una suerte de espejo de don Quijote.

\subsection{Penitencia y separación}

Inspirado, quizás, por Cardenio, don Quijote decide hacer penitencia por Dulcinea del Toboso, a quien Sancho ha de llevar de su amo una carta de amor.

\footnotetext{
${ }^{13}$ Ibídem, p. 211.

${ }^{14}$ Ibídem, pp. 215-216.

${ }^{15}$ Ibídem, p. 220.
} 
Ésa es la delicada embajada que don Quijote le encomienda a su amigo, a quien le presta nada menos que Rocinante, porque Sancho parece haber perdido a su rucio. En la carta, don Quijote le advierte a Dulcinea que hasta que ella acuda a rescatarlo, él quedará sumido en la más despiadada penitencia.

Dulcinea no le ha dado causa a don Quijote para hacer penitencia: nunca le ha sido infiel, que él sepa. Pero eso mismo ennoblece la acción de don Quijote. “[É]sa es la fineza de mi negocio", explica él, siempre ajeno a la necesidad de tener mezquinas razones para actuar y siempre privilegiando el arrojo sobre el cálculo, ya que "volverse loco un caballero andante con causa, ni grado ni gracias"16. Nunca tan loco, claro: Don Quijote decide, tras tortuosas racionalizaciones, imitar las "melancólicas" locuras de Amadís de Gaula, y no las "desaforadas", y mucho más arduas, "locura de Roldán"17.

Justo antes de tomar esta sabia decisión, don Quijote empieza a desvestirse delante de Sancho, para que éste constate su condición de penitente loco. Al hacerlo, al desnudarse incluso "a toda priesa los calzones", quedándose "en carnes y en pañales", don Quijote descubre sus intimidades, "cosas que, por no verlas otra vez, volvió Sancho la rienda a Rocinante". Sancho parte dándose "por contento y satisfecho de que podía jurar que su amo quedaba loco"18. Esta preciosa escena en que Sancho evita detenerse en la intimidad de su amo, es una de las muchas en que los amigos recurren al sabio expediente de cerrar los ojos. La amistad de don Quijote y Sancho está basada, como quizás todas las amistades, en el dictamen de T.S. Eliot, de que la vida no tolera mucha realidad.

La embajada de Sancho es corta. Él parte a ver a Dulcinea. Ésta, según don Quijote ha explicado por primera vez, es nada menos que Aldonza Lorenzo, que probablemente "no sabe escribir ni leer", que él no ha visto más de cuatro veces, "y aun podrá ser que de estas cuatro veces no hubiese ella echado de ver la una que la miraba"19. Pero en el camino Sancho se encuentra con el cura y el barbero, esos amigos intrusos de don Quijote que quieren rescatarlo de la caballería. Además Sancho descubre que ha perdido la carta de don Quijote a Dulcinea. Enseguida aparece Dorotea, la belleza despechada por Fernando, que arrebató a Luscinda de Cardenio: la intromisión y entrelazamiento de las complejísimas novelas de amor insertadas dentro del Quijote empezarán desde acá a encaminarse hacia esa deliciosa

\footnotetext{
${ }^{16}$ Ibídem, p. 236.

${ }^{17}$ Ibídem, p. 249.

${ }^{18}$ Ibídem, p. 248.

${ }^{19}$ Ibídem, p. 242.
} 
cúspide que se dará cuando los dispersos personajes se reencuentran en la venta en que Sancho fue manteado. Enseguida el cura, el barbero y Dorotea urden un plan para sacar a don Quijote de la Sierra Morena. De acuerdo al plan, Dorotea, que ha leído muchos libros de caballería, dirá que ella es la princesa Micomicona, y le pedirá a don Quijote que salga de la sierra para lidiar con Pandafilando de la Fosca Vista, un descomunal gigante que se ha acaparado de su reino.

\subsection{Los dobles juegos de Sancho}

A partir de esta conspiración y del regreso de Sancho a la Sierra Morena con el cura, el barbero y Dorotea, se da una serie de cambios en la forma y el fondo de la relación entre don Quijote y Sancho, y de ambos con los demás. Sancho le miente a don Quijote, diciéndole que ha estado con Dulcinea y que le ha entregado la carta o una versión recordada de ella. Sancho en sus mentiras entra incluso en detalles muy precisos: "sentí un olorcillo algo hombruno, y debía de ser que ella, con el mucho ejercicio, estaba sudada y algo correosa" ${ }^{20}$. Don Quijote sospecha que Sancho miente, pero no quiere saber demasiado. "Me parece que fuiste y viniste por los aires", le dice, "pues poco más de tres días has tardado en ir y venir desde aquí al Toboso, habiendo de aquí allá más de treinta leguas"21. Pero como no quiere sacar conclusiones que no le convienen, don Quijote concluye que Sancho ha sido ayudado por encantadores amigos.

Hay otra novedad que se da con el regreso de Sancho y su séquito a la Sierra Morena. No solo se urde un plan para engañar a don Quijote, presentándole una princesa Micomicona que responde a todas sus fantasías, creándole un espectáculo compatible con estar viviendo dentro de una novela de caballería, como lo harán en forma mucho más elaborada los Duques en la Segunda Parte. Hay en este engaño un importante matiz. A diferencia de los espectáculos de los Duques, Sancho se volverá cómplice del engaño, sabrá que la princesa Micomicona es Dorotea. Pero eso no le impedirá estar feliz de que, al matar al gigante enemigo de la princesa, don Quijote acceda a un reino, y esté por tanto en condiciones de proveerle a Sancho una ínsula. Por un tiempo, Sancho había temido que don Quijote quisiera ser arzobispo.

${ }^{20}$ Ibídem, p. 312. Será recurrente en el libro la tendencia a atribuirle rasgos hombrunos a Dulcinea y a otras mujeres idealizadas por don Quijote. Los Duques harán que un hombre se disfrace de Dulcinea, y después de la Condesa Trifaldi. Este humor travesti de Cervantes es uno de los muchos expedientes usados para reducir los sueños de don Quijote al chacoteo de la comedia de golpes y porrazos.

${ }^{21}$ Cervantes, Don Quijote, op. cit., p. 313. 


\section{Las características de la amistad}

\subsection{Un proyecto de vida compartida}

Cuando bajan de la Sierra Morena y llegan de nuevo a la venta (a la que Sancho rehúsa entrar, dado el manteamiento que allí sufrió), ya están dadas las principales características de la amistad de don Quijote y Sancho.

Es una amistad en que un amigo ha invitado a otro a su proyecto de vida, porque necesita un testigo, un cómplice: ¿qué son sus hazañas si no hay un testigo común a todas ellas? Un proyecto de vida que nace de un acto de voluntad. Como dice don Quijote al ama y la sobrina, “. . . será en balde cansaros en persuadirme a que no quiera yo lo que los cielos quieren, la fortuna ordena y la razón pide, y, sobre todo, mi voluntad desea"22.

Es un proyecto que como estrategia de vida, como terapia para la vida, privilegia la "buena esperanza a la ruin posesión". "Lea esos libros" le aconseja don Quijote al Caballero del Lago, cuando le explica las bondades de las novelas de caballería, "y verá cómo le destierran la melancolía que tuviere y le mejoran la condición, si acaso la tiene mala"23. Es así como don Quijote se construye una vida como antídoto a las tristezas y las frustraciones que lo han agobiado como solterón cincuentón, sumido en la pobreza. En cuanto a Sancho, él también siente el llamado de la ilusión y la esperanza. "Sancho nací y Sancho pienso morir" dice, "pero si con todo esto, de buenas a buenas, sin mucha solicitud y sin mucho riesgo, me deparase el cielo alguna ínsula, o otra cosa semejante, no soy tan necio, que la desechase; que también se dice 'cuando te dieren la vaquilla, corre con la soguilla', y 'cuando viene el bien, mételo en tu casa'" 24 .

Es un proyecto de vida, éste, que privilegia el pasado, la edad de oro en que todo era paz y todos compartían todo, en que los caballeros andantes imponían el bien con su lanza mostrándole la cara al enemigo, porque no existían esos viles y mezquinos cañones que son disparados desde un miserable escondite.

\subsection{La complicidad en el entendimiento}

La estrategia para vivir este proyecto de vida tan contra viento y marea es una que se da espontáneamente entre don Quijote y Sancho. Es una estrategia de complicidad para adecuar la realidad a los requerimientos de la voluntad y del deseo, una especie de pacto epistemológico tácito.

\footnotetext{
22 Ibídem, p. 592.

${ }^{23}$ Ibídem, p. 511.

${ }^{24}$ Ibídem, p. 579.
} 
Nunca en forma absoluta, sino lo suficiente para seguir disfrutando. La complicidad que se va urdiendo se va dando en forma espontánea, como reacción a una y otra experiencia nueva.

Muchas veces se da a regañadientes. Por ejemplo don Quijote insiste en que Sancho acepte que la bacía de barbero es el yelmo de Mambrino. Sancho va cediendo y acepta que al menos es un "baciyelmo". Pero don Quijote le devuelve la mano sólo a medias. Rehúsa confirmar que la albarda que Sancho le ha arrebatado al barbero es un jaez de caballo, como sostiene Sancho para justificarse. "A mí albarda me parece", dice don Quijote, en medio de la batahola epistemológica que se da en la venta sobre el tema, antes de que se decida llegar a la verdad en forma democrática, sometiendo la cuestión a un voto secreto ${ }^{25}$.

Esa complicidad ante los hechos, para interpretar qué es verdad, la van improvisando don Quijote y Sancho una y otra vez.

Nunca más que cuando los Duques prueban su credulidad proveyéndoles de espectáculos sacados de novelas de caballería, como el de la condesa Trifaldi y sus doce dueñas, que han sido encantadas por el gigante Malambruno, en virtud de lo cual les han crecido barbas. Como el reino de Candilandia donde está Malambruno queda a tres mil leguas, don Quijote y Sancho se montarán en Clavileño, un caballo de madera que, regido por una clavija en el cuello, cubre grandes distancias en pocos instantes. Al volver del "viaje", Sancho dice haber visto cosas extraordinarias. Dice que desde las alturas, vio la tierra "y pareciome que toda ella no era mayor que un grano de mostaza, y los hombres que andaban sobre ella, poco mayores que avellanas" 26 . Enseguida Sancho se vuelve aún más extravagante, entrando con sus mentiras en detalles tan insólitos como precisos. "Y sucedió que íbamos por parte donde están las siete cabrillas", dice

[Y] en Dios y en mi ánima que como yo en mi niñez fui cabrerizo, que así como las vi, me dio una gana de entretenerme con ellas un rato, que si no la cumpliera me parece que reventara. Vengo, pues, y tomo ¿y qué hago? Sin decir nada a nadie, ni a mi señor tampoco, bonita y pasitamente me apeé de Clavileño y me entretuve con las cabrillas, que son como unos alhelíes y como unas flores, casi tres cuartos de hora, y Clavileño no se movió de un lugar ni pasó adelante ${ }^{27}$.

Don Quijote lo escucha atónito. Él ha tenido una experiencia solo, sin el testimonio de Sancho: su bajada, atado a una soga, a la cueva de

${ }^{25}$ Ibídem, p. 467.
${ }^{26}$ Ibídem, p. 863.
${ }^{27}$ Ibídem, p. 863. 
Montesinos, donde se encontró con personajes de novelas de caballería y también con Dulcinea del Toboso, transformada en ruda labradora: todos en la cueva estaban bajo el encantamiento de Merlín. Sancho intuye que la visión de la cueva tiene que ser falsa, porque la labradora que don Quijote cree es Dulcinea encantada, es una mujer que él al azar identificó a don Quijote como Dulcinea sólo para sacarse del apuro de que nunca cumplió su embajada y nunca la vio. Don Quijote por su parte sabe que Sancho montado en Clavileño no pudo haber visto lo que dice. Es así que don Quijote toma a Sancho a un lado y le propone, no sin ironía, un pacto epistemológico, esta vez explícito. "Sancho" le dice, "pues vos queréis que se os crea lo que habéis visto en el cielo, yo quiero que vos me creáis a mí lo que vi en la cueva de Montesinos. Y no os digo más"28.

Más adelante, Sancho observará de cerca a un mayordomo del Duque y le parecerá que su rostro se parece sospechosamente al de la Condesa Trifaldi. Don Quijote no puede negarlo, pero decide no atribuirle demasiada importancia.

No hay para que te lleve al diablo, Sancho, ni en justo ni en creyente, que no sé lo que quieres decir: que el rostro de la Dolorida es el del mayordomo, pero no por eso el mayordomo es la Dolorida, que a serlo, implicaría contradicción muy grande, y no es tiempo ahora de hacer estas averiguaciones, que sería entrarnos en intrincados laberintos ${ }^{29}$.

Sancho no insiste demasiado. Después de todo, la curiosidad mata el gato. Y para quien lo dude, está esa novela dentro de la novela, esa importante novela interior que se llama "El curioso impertinente", y que por contraste ilumina lo que es la amistad de don Quijote y Sancho y su forma de entender el mundo.

\subsection{La importancia de no saber demasiado}

En "El curioso impertinente", Anselmo duda, sin causa alguna, de la lealtad de la bella Camila, su mujer perfecta. En realidad no es tanto que dude, sino que quiere ver comprobado ante testigos, y más allá de cualquier duda, que ella le es férreamente leal, que ella es tan perfecta como parece. Por eso le pide a Lotario, su mejor amigo, un descomunal favor. Que él trate de seducir a Camila. Que trate y falle, claro. Anselmo desarrolla la teoría de que no es comprobada la virtud de una mujer hasta ser probada.

\footnotetext{
${ }^{28}$ Ibídem, p. 865.

${ }^{29}$ Ibídem, pp. 878-879.
} 
¿Qué mucho que esté recogida y temerosa la que no le dan ocasión para que se suelte, y la que sabe que tiene marido que en cogiéndola en la primera desenvoltura la ha de quitar la vida? Así que la que es buena por temor o por falta de lugar, yo no la quiero tener en aquella estima en que tendré a la solicitada y perseguida que salió con la corona del vencimiento $^{30}$.

Lotario usa todo argumento a su alcance para disuadir a su amigo, pero Anselmo es incapaz de tener fe sin pruebas. Es incapaz de entender que al poner a prueba al objeto de su fe, al poner a prueba a Camila, ya empaña su virtud. La mujer que no es creída por su marido, por pura que sea, ya es una mujer caída, porque no le basta ser pura a quien no parece serlo, y porque si la opinión de quien más la conoce es mala, poco se puede esperar de la opinión de los demás. Y si es así, ya no tiene nada que perder. No nos sorprende cuando Camila cae en la tentación. Et ne nos inducat: no es por nada que pedimos en la oración al Padre no ser conducidos por Él a la tentación. Por conducir a Camila a la tentación, Anselmo abre las compuertas de la desgracia.

Anselmo y don Quijote son la antítesis el uno del otro. Uno está empeñado en no creer. El otro en creer. Anselmo tiene que ver para creer. Para don Quijote, la gracia es creer sin ver. A los mercaderes les dice de la belleza de Dulcinea: "la importancia está en que sin verla lo habéis de creer, confesar, afirmar, jurar y defender" 31 . Es que cualquiera cree viendo.

Curiosamente tanto Anselmo como don Quijote forjan profecías autocumplidas. Lo que Anselmo está empeñado en no creer, la pureza de su mujer, finalmente deja de existir por obra suya. Lo que la fe niega, en los hechos se disuelve. En cambio lo que don Quijote está empeñado en creer, cobra, con la complicidad de Sancho y otros, cada vez más vida. Los hechos se le hacen cada vez menos porfiados.

A veces, don Quijote logra construir un mundo a partir de la fe pura, a partir de la pura idea. Así es la construcción de Dulcinea del Toboso, cuya belleza es más insuperable y sólida que cualquier realidad, porque es una construcción de la voluntad hecha de acuerdo a cánones universales:

[E]n ella se vienen a hacer verdaderos todos los imposibles y quiméricos atributos de belleza que los poetas dan a sus damas: que sus cabellos son oro, su frente campos elíseos, sus cejas arcos del cielo, sus ojos soles, sus mejillas rosas, sus labios corales, perlas sus dientes, alabastro su cuello, mármol su pecho, marfil sus manos, su blancura nieve, y las partes

\footnotetext{
${ }^{30}$ Ibídem, p. 331

${ }^{31}$ Ibídem, p. 53.
} 
que a la vista humana encubrió la honestidad son tales, según yo pienso y entiendo, que sólo la discreta consideración puede encarecerlas, y no compararlas ${ }^{32}$.

Más tarde, cuando la Duquesa le pregunta a don Quijote si es verdad que Dulcinea es una invención, ya que se dice que él nunca la ha visto, éste le contesta que no puede ser una invención, porque su figura obedece a todas las convenciones que describen a la dama de un caballero andante,

[P] uesto que la contemplo como conviene que sea una dama que contenga en sí las partes que puedan hacerla famosa en todas las del mundo, como son hermosa sin tacha, grave sin soberbia, amorosa con honestidad, agradecida por cortés, cortés por bien criada, $y$, finalmente, alta por linaje . . .33

Cualquier Dulcinea "real" sería, en su inasible individualidad, escurridiza al lado de esta inobjetable e irrefutable Dulcinea ideal.

\subsection{Los vaivenes de la lealtad}

La amistad de don Quijote y Sancho tiene sus puntos altos y bajos. A veces Sancho lo engaña a don Quijote. Lo engaña en cuanto a la embajada a Dulcinea. Después lo engaña cuando dice que la primera labradora que ve es Dulcinea. Persiste en este último engaño durante el resto de la vida de don Quijote. Pero Sancho es insólitamente leal a don Quijote. Cuando Merlín dice que Dulcinea será desencantada sólo cuando Sancho se dé 3.300 azotes, Sancho acepta el reto, por mucho que sepa que no es por encantamiento que Dulcinea parece labradora. Claro que Sancho posterga los azotes y después engaña a don Quijote una vez más, haciéndole creer que se está azotando, cuando no lo está. Don Quijote por su lado engaña a Sancho constantemente con sus promesas de ínsulas: la única diferencia es que el narrador hace que los engaños de don Quijote sean menos explícitos, dándonos lugar a creer que don Quijote no sabe que está engañado a Sancho.

Don Quijote y Sancho son a veces férreamente leales el uno al otro, a veces no. En el fragor de la batalla con frecuencia se ayudan, pero no siempre. Uno tiende a pensar que es Sancho el que se salva mientras pueda, pero don Quijote lo deja en la venta cuando es manteado, y en el incidente del pueblo de los rebuznos, don Quijote huye desvergonzadamente sin ayudar a Sancho, mientras a éste le dan una tremenda paliza. El incidente dará

\footnotetext{
32 Ibídem, p. 115.
}

33 Ibídem, p. 800. 
lugar a una de las grandes pero breves peleas que tienen don Quijote y Sancho. La peor - la única en que se agarran físicamente - será camino a Barcelona, cuando están discutiendo si los azotes ordenados por Merlín han de ser voluntarios u obligados.

Como en toda amistad, entre don Quijote y Sancho hay intereses en juego. A don Quijote le interesa tener un testigo que convalide su visión, y por último también un criado que le lleve las cosas. A Sancho, le interesa la ínsula, pero aun después de gobernar la ínsula, aun cuando sabe que ya no habrá más ínsulas, opta por seguir con su amo, aun cuando sea en el proyecto pastoril que éste concibe cuando van de regreso al pueblo por última vez. ¡Es que el proyecto de vida que han forjado en común es entretenido, mucho más que quedarse en casa!

Pero con todo, hay una relación contractual de amo y criado entre los dos, y ésta da lugar a repetidas discusiones, en que don Quijote, con visión de empresario acostumbrado al riesgo, insiste que el pago de Sancho sea en base al éxito de las aventuras, y Sancho, con su visión de empleado averso al riesgo, que haya una remuneración fija.

Siendo personajes en tantas cosas tan obviamente parecidos, la gran diferencia entre los dos es justamente que don Quijote es el emprendedor, el creativo, el inventor de las aventuras, y Sancho el seguidor, el que hace a su manera lo que el amo manda. Es en base a esa gran diferencia que, después del pleito entre el bachiller y el licenciado, y antes de asistir a las bodas de Camacho, don Quijote le rinde un conmovedor homenaje a Sancho mientras éste ronca.

¡Oh tú, bienaventurado sobre cuantos viven sobre la haz de la tierra [piensa don Quijote], pues sin tener envidia ni ser envidiado duermes con sosegado espíritu, ni te persiguen encantadores ni sobresaltan encantamientos! Duermes, digo otra vez, y lo diré otras ciento, sin que te tengan en continua vigilia celos de tu dama, ni te desvelen pensamientos de pagar deudas que debas, ni de lo que has de hacer para comer otro día tú y tu pequeña y angustiada familia. Ni la ambición te inquieta, ni la pompa vana del mundo te fatiga, pues los límites de tus deseos no se extienden a más que a pensar tu jumento, que el de tu persona sobre mis hombros le tienes puesto, contrapeso y carga que puso la naturaleza y la costumbre a los señores. Duerme el criado, y está velando el señor pensando cómo le ha de sustentar, mejorar y hacer mercedes. La congoja de ver que el cielo se hace de bronce sin acudir a la tierra con el conveniente rocío no aflige al criado, sino al señor, que ha de sustentar en la esterilidad y hambre al que le sirvió en la fertilidad y abundancia ${ }^{34}$.

${ }^{34}$ Ibídem, pp. 697-698. 


\subsection{La agonía de la separación}

Estos dos amigos llegan a convivir tanto que comparten las más grandes intimidades. Vomitan el uno sobre el otro. Se curan las heridas. Defecan vestidos mientras duermen, con la esperanza que el otro no se dé cuenta $^{35}$. Pero siempre hay pudor. Respeto por la intimidad del otro. Límite a la peligrosa curiosidad. Respeto por las creencias del otro: se le contradice con mesura cuando corresponde y se le sigue el humor cuando no hacerlo no tiene sentido. Aceptación del otro como es, por mucho que a menudo sea imposible resistir corregirlo. Delicadeza, tino. No es sorprendente entonces que la enormidad de esta amistad se manifieste cuando don Quijote y Sancho son separados, por ser Sancho elegido por los Duques a ser gobernador de la ínsula Barataria.

No es ese un buen momento para quedarse solo don Quijote. Está deprimido: las novelas de cabellaría ya no lo están alejando como antes de la melancolía. ¿Será que en su fuero interno sabe que los Duques lo están engañando? ¿Que sabe o intuye que esos espectáculos nocturnos son falsos? ¿Que la gota que rebalsó el vaso fue hacerle creer que volaba por el cielo montado en un caballo de madera? Una cosa es que él invente la aventura, otra que se la inventen a él. Además tal vez le retumben todavía en el oído las palabras de Sancho, cuando le dice que el rostro del mayordomo es igual al de la Condesa Trifaldi. ¿Sólo el rostro? ¡Sancho ha dicho que la voz también! Pero si lo están engañado, ¿cómo admitirlo, siquiera a sí mismo? Porque, ¿quién sino un desgraciado se prestaría no sólo a ser engañado, sino a hacer un espectáculo delante de cientos de personas, el espectáculo, sobre todo, de ser el único que no sabe que lo están engañado?

En todo caso don Quijote está deprimido por la sola ida de su escudero. "Cuéntase", dice el narrador, "pues, que apenas se hubo partido Sancho, cuando don Quijote sintió su soledad"36. Es en esa condición que don Quijote se retira a sus aposentos, habiendo rehusado, por pudor, que lo asistan las cuatro doncellas que la Duquesa le ha ofrecido. Es allí donde se da la escena que, según Nabokov, es la más sublime del libro, la escena en que, desvistiéndose solo, se le suelta una de las medias ${ }^{37}$. "De nuevo

${ }^{35} \mathrm{La}$ necesidad de defecar o eructar, como en general los malos olores que emanan del cuerpo, se manifiestan constantemente en la novela como contrapunto al idealismo de los héroes.

${ }^{36}$ Ibídem, p. 879.

37 Vladimir Nabokov, Lectures on Don Quixote (Hartcourt Brace Jovanovich Inc., 1983), pp. 68-69. Nabokov, en estas conferencias que dictó en Harvard en 19511952, fue muy severo con la novela, por creerla cruel, hasta sádica, pero sostiene que en esta escena Cervantes se asoma a la cúspide del arte. 
nuevas gracias dio don Quijote a la duquesa”, parte el narrador, y continúa que:

en cenando don Quijote se retiró en su aposento solo, sin consentir que nadie entrase con él a servirle: tanto se temía de encontrar ocasiones que le moviesen o forzasen a perder el honesto decoro que a su señora Dulcinea guardaba, siempre puesta en la imaginación la bondad de Amadís, flor y espejo de los andantes caballeros. Cerró tras sí la puerta, y a la luz de dos velas de cera se desnudó, y al descalzarse, joh desgracia indigna de tal persona!, se le soltaron, no suspiros ni otra cosa que desacreditasen la limpieza de su policía, sino hasta dos docenas de puntos de una media, que quedó hecha celosía. Afligiose en extremo el buen señor, y diera él por tener allí un adarme de seda verde una onza de plata (digo seda verde porque las medias eran verdes $)^{38}$.

En esta escena se ve lo vulnerable que es el orgulloso caballero andante. Vulnerable por la fragilidad de las ideas con que sustenta su mundo, vulnerable porque es pobre y porque no tiene más medias, vulnerable sobre todo porque no sabe cuándo ha de ver a su amigo: no vaya a ser que se asiente como gobernador de la ínsula, que el puesto sea vitalicio. Es en esta escena que uno ve la enormidad de la brecha entre el mundo que don Quijote se construye para su proyecto de vida, y la poco promisoria realidad a la que el proyecto se tiene que sobreponer. Es allí donde apreciamos la inmensidad del acto de voluntad de don Quijote y de sus hazañas.

En realidad en sus días a solas con los Duques, don Quijote lo pasa pésimo. Es asediado con majadera insistencia por la bella Altisidora, que dice morir de pasión por él, poniendo a prueba su lealtad a Dulcinea. Es atacado por gatos que invaden su aposento y que le arañan la cara. Después es atacado hasta por la misma Duquesa. Sin Sancho, la vida de don Quijote en el castillo de los Duques es una catástrofe.

¿Qué es de Sancho Panza mientas tanto? Al comienzo Sancho está demasiado concentrado en el buen gobierno de su ínsula para extrañar demasiado a su amo. Pero no hay duda que está feliz cuando de don Quijote recibe una carta.

Sancho desde luego sorprende a todos con la sabiduría salomónica con que toma sus decisiones. Algunos dirán que Sancho simplemente demuestra que cualquiera puede gobernar cuando le dan la oportunidad, que el carisma es producto del poder, y no al revés como a veces se cree. Pero

${ }^{38}$ Cervantes, Don Quijote, op. cit., pp. 881-882. 
en realidad las decisiones que toma Sancho al dirimir disputas son mucho más sensatas que las qué él le ha visto a su propio amo en el transcurso de las aventuras. Claro que Sancho también es engañado por los Duques: los habitantes de la ínsula tienen instrucciones de obedecerlo y de hacerlo creer que él es efectivamente el gobernador. ¿Pero no es así el poder? ¿No son así los cortesanos siempre hasta que alguien ose decir que el emperador va desnudo? ${ }^{39}$

En todo caso la gloria de ser gobernador se esfuma para Sancho cuando a la ínsula le declaran la guerra. El gobernador no tiene espíritu bélico. Se escapa y huye hacia el castillo de los Duques, para juntarse otra vez con don Quijote. Antes de llegar, ya de noche, Sancho, montado en su rucio, cae de repente "en una honda y escurísima sima" ${ }^{40}$. Cae ileso, pero no encuentra la salida. Se asusta. En la soledad de la noche, se lamenta de la vana ambición que lo ha llevado a querer ser gobernador, en vez de ser fiel a sí mismo, y empieza a extrañar a don Quijote como nunca. "¡Válame Dios todopoderoso!" dice entre sí y continúa:

Ésta que para mí es desventura, mejor fuera para aventura de mi amo don Quijote. Él sí que tuviera estas profundidades y mazmorras por jardines floridos y por palacios de Galiana, y esperara salir de esta escuridad y estrecheza a algún florido prado; pero yo sin ventura, falto de consejo y menoscabado de ánimo, a cada paso pienso que debajo de los pies de improviso se ha de abrir otra sima más profunda que la otra, que acabe de tragarme ${ }^{41}$.

Felizmente, es justamente don Quijote quien lo rescata. Al fin el amo y el escudero se reencuentran. Ya no se han de separar.

\subsection{La libertad compartida}

Pronto después, don Quijote les explica a los Duques que es tiempo de partir: la caballería andante lo llama. En realidad, con los Duques, don Quijote y Sancho han vivido una profunda contradicción, de la cual don Quijote parece estar tomando conciencia. En vez de vivir libres, de acuerdo

${ }^{39}$ En El otoño del patriarca, Gabriel García Márquez encarnará una versión moderna de esa pregunta. Inventará a un centenario dictador que se cree omnipotente porque sus súbditos por astucia lo aclaman como tal. Él no sabe que hasta las noticias que ve en su televisor son inventadas por sus cortesanos.

${ }^{40}$ Cervantes, Don Quijote, op. cit., p. 968.

${ }^{41}$ Ibídem, p. 970. 
a su voluntad (o la de Rocinante, ya que en la novela es el caballo el que generalmente decide donde ir) ${ }^{42}$, don Quijote y Sancho han sido los esclavos de una representación montada por los Duques para engañarlos.

Don Quijote, como buen hombre del Renacimiento, efectivamente ve el mundo como una representación, una comedia: le explica a Sancho que lo es después del episodio de la carreta de los representantes. Pero para don Quijote la bondad de ese hecho está en que por consecuencia, él puede decidir qué papel actuar. De allí la emocionada alabanza a la libertad que le hace don Quijote a Sancho cuando finalmente se liberan de los Duques, expresando emociones muy parecidas a las que ha tenido Sancho al renunciar a la gobernación, mostrando que en el fondo los dos tienen los mismos valores. Los dos valoran sobre todo la autonomía, la libertad, la sensación de independencia que les da la búsqueda de aventuras al azar. Es por esa independencia que ya dos veces han salido, como niños chicos, en la noche de su pueblo, sin despedirse de sus familias. Es por esa independencia que han estado dispuestos a sufrir tantas penurias. Esa independencia la han traicionado mientras han vivido con los Duques. Para vivir en lujo y comodidad, han cambiado un mundo hecho a su voluntad, por un mundo creado y representado por los Duques. Por eso al liberarse de los Duques un aliviado don Quijote dice:

La libertad, Sancho, es uno de los más preciosos dones que a los hombres dieron los cielos; con ella no pueden igualarse los tesoros que encierran la tierra ni el mar encubre; por la libertad así como por la honra se puede y debe aventurar la vida, y, por el contrario, el cautiverio es el mayor mal que pueda venir a los hombres. Digo esto, Sancho, porque bien has visto el regalo, la abundancia que en este castillo que dejamos hemos tenido; pues en mitad de aquellos banquetes sazonados y de aquellas bebidas de nieve me parecía a mí

${ }^{42}$ Las aventuras de don Quijote son un acto de voluntad pero también uno de entrega, sobre todo de rechazo al cálculo, a la reflexión. Entrega al heroísmo pero también al noble azar, representado, muchas veces, por los caprichos de Rocinante. Desde su primera salida, todavía sin Sancho, don Quijote "prosiguió su camino, sin llevar otro que aquel que su caballo quería, creyendo que en aquello consistía la fuerza de las aventuras" (p. 35). Más adelante, cuando don Quijote se hace del yelmo de Mambrino, él y Sancho "subieron a caballo, y sin tomar determinado camino, por ser muy de caballeros andantes el no tomar ninguno cierto, se pusieron a caminar por donde la voluntad de Rocinante quiso, que se llevaba tras sí la de su amo, y aún la del asno, que siempre lo seguía por dondequiera que guiaba, en buen amor y compañía" (p. 192). Y cuando hallan la maleta con los escudos de oro en la Sierra Morena, es porque andaban "sin llevar otro camino que aquel que Rocinante quería - que era por donde él podía caminar-" (p. 216), un ejemplo de los réditos que da el arrojo sin cálculo del caballero andante y su escudero. 
que estaba metido entre las estrechezas de la hambre, porque no lo gozaba con la libertad que lo gozara si fueran míos, que las obligaciones de las recompensas de los beneficios y mercedes recibidas son ataduras que no dejan campear al ánimo libre. ¡Venturoso aquel a quien el cielo dio un pedazo de pan sin que le quede obligación de agradecerlo a otro que al mismo cielo! ${ }^{43}$

Claro que el ideal de don Quijote de no deberle nada a nadie es difícil de sostener cuando se tiene sólo un par de medias.

\subsection{Las representaciones de la voluntad y la muerte}

La vida es representación y comedia pero termina en la muerte, el fin de la comedia. Don Quijote y Sancho habían discutido la idea a fondo, más o menos a mitad camino, cuando todavía tenían tantas aventuras por delante:

¿[No] has visto tú representar alguna comedia adonde se introducen reyes, emperadores y pontífices, caballeros, damas y otros diversos personajes? Uno hace el rufián, otro el embustero, éste el mercader, aquél el soldado, otro el simple discreto, otro el embustero, éste el mercader, aquél el soldado, otro el simple discreto, otro el enamorado simple; y acabada la comedia y desnudándose de los vestidos de ella, quedan todos los recitantes iguales.

- Sí he visto — respondió Sancho.

- Pues lo mismo - dijo don Quijote - acontece en la comedia y trato de este mundo, donde unos hacen los emperadores, otros los pontífices, y finalmente todas cuantas figuras se pueden introducir en una comedia; pero en llegando al fin, que es cuando se acaba la vida, a todos les quita la muerte las ropas que los diferenciaban, y quedan iguales en la sepultura. - Brava comparación - dijo Sancho-, aunque no tan nueva, que yo no la haya oído muchas y diversas veces, como aquella del juego del ajedrez, que mientras dura el juego cada pieza tiene su particular oficio, y en acabándose el juego todas se mezclan, juntan y barajan, y dan con ellas en una bolsa, que es como dar con la vida en la sepultura.

- Cada día, Sancho - dijo don Quijote-, te vas haciendo menos simple y más discreto ${ }^{44}$.

\footnotetext{
${ }^{43}$ Cervantes, Don Quijote, op. cit., pp. 984-985.

${ }^{44}$ Ibídem, pp. 631-632.
} 
Esta entretenida discusión viene a la mente cuando don Quijote y Sancho vuelven a su pueblo por última vez. Pronto, don Quijote se enferma y entiende que morirá. Muchos lectores objetan que en ese momento, don Quijote reniegue de la caballería andante, diga que no es caballero andante y se arrepienta ante su confesor de haber pretendido serlo.

No comparto la objeción. Es que se acabó la comedia: jla comedia e finita! Es muy lógico dentro de sus propios términos, que don Quijote reniegue de una profesión conquistada por acto de voluntad, que le ha dado un gran proyecto de vida, pero que no le sirve al morir. Finalmente lo que hay que confesar es el papel que uno jugó, la máscara que uno se puso, para disfrazar la calavera, y eso es lo que hace don Quijote. El concepto de que haya que confesar y deponer todo lo que uno fue, o todo lo que con la voluntad uno quiso ser, está en el Renacimiento, está en el barroco español de la Contra Reforma, está en la sabiduría de vida y de muerte de todos los pueblos en todas las épocas. Por eso creo que los lectores que critican a don Quijote por botar la toalla al morir están equivocados: sea o no la forma en que uno quiera morir, tiene su lógica implacable.

También creo equivocados a los lectores que critican a Sancho Panza por no estar a la altura de la muerte de su amigo. Mientras que un don Quijote moribundo se acuerda de Sancho al escribir su testamento, Sancho no muestra el dolor que algunos lectores le exigen.

Cerró con esto el testamento y, tomándole un desmayo, se tendió de largo a largo en la cama. Alborotáronse todos y acudieron a su remedio, y en tres días que vivió después de este donde hizo el testamento se desmayaba muy a menudo. Andaba la casa alborotada, pero, con todo, comía la sobrina, brindaba el ama y se regocijaba Sancho Panza, que esto del heredar algo borra o templa en el heredero la memoria de la pena que es razón que deje el muerto ${ }^{45}$.

Sancho no muestra todo el dolor que algunos le exigen, pero ¿quién no se alegra al heredar? La gracia de esta gran amistad de don Quijote de la Mancha y Sancho Panza es que es una amistad real, de dos individuos de carne y hueso, y no la amistad de dos estereotipos —el gordo y el flaco, el realista y el idealista, el sensato y el temerario - de una leyenda que parece haber sido urdida por lectores que no llegaron más allá del episodio de los molinos de viento.

${ }^{45}$ Ibídem, p. 1104. 